\title{
PEMBELAJARAN ANTARA MINAT MEMBACA DAN MOTIVASI BELAJAR SISWA KELAS V SDN KAROLINA
}

\author{
Ina Magdalena ${ }^{1}$, Marifatul Ulfah ${ }^{2}$, Siti Zaedatun Nikmah ${ }^{3}$ \\ Universitas Muhammadiyah Tangerang \\ inapgsd@gmail.com , ulfahmarifatul11@gmail.com
}

\begin{abstract}
The development of learning to read can be done through the use of three channels of character education implementation, namely through teaching materials, learning models, and authentic assessment. Authentic assessment is the most important channel because the use of authentic assessment will include the selection of teaching materials and learning models. Authentic assessment guides learning through the creation of various learning activities carried out by students during the learning process which contains character content. Learning between Reading Interest and Learning Motivation of Class V SDN KAROLINA Students. The purpose of this study was to obtain clarity and objective information about learning between reading interest and learning motivation of grade V SDN KAROLINA students. The method used in this research is descriptive method with the form of research is a learning study. This means that there is significant learning between reading interest and learning motivation of grade $V$ SDN KAROLINA students.
\end{abstract}

Keywords: Learning, Reading Interest,, Creative, Learning Motivation

\begin{abstract}
Abstrak : Pengembangan pembelajaran membaca dapat dilakukan melalui pemanfataan tiga saluran penerapan pendidikan karakter, yaitu melalui bahan ajar, model pembelajaran, dan penilaian otentik. Penilaian otentik merupakan saluran yang paling penting sebab penggunaan penilaian otentik akan mencakup pemilihan bahan ajar dan model pembelajaran. Penilaian otentik memandu pembelajaran melalui pengreasian berbagai aktivitas belajar yang dilakukan siswa selama proses pembelajaran yang di dalamnya terkandung muatan karakter. Pembelajaran antara Minat dengan Motivasi Belajar Siswa Kelas V SDN KAROLINA. Tujuan penelitian ini adalah untuk memperoleh kejelasan dan informasi yang objektif tentang pembelajaran antara minat membaca dengan motivasi belajar siswa kelas V SDN KAROLINA. Metode yang digunakan dalam penelitian ini adalah metode deskriptif dengan bentuk penelitiannya adalah studi pembelajaran. Ini berarti bahwa terdapat pembelajaran yang signifikan antara minat membaca dengan motivasi belajar siswa kelas V SDN KAROLINA.
\end{abstract}

Kata Kunci: Pembelajaran, Minat Membaca, Motivasi Belajar 


\section{PENDAHULUAN}

Pembelajaran merupakan aktivitas yang paling utama. Hal ini berarti bahwa keberhasilan suatu individu dalam pencapaian tujuan pendidikan banyak bergantung pada bagaimana pembelajaran dapat berlangsung secara efektif. Pembelajaran merupakan suatu proses yang dilakukan dengan memberikan pendidikan dan pelatihan kepada peserta didik untuk mencapai hasil belajar (Sudjana,2000). Perubahan sebagai hasil proses belajar dapat diajukan dalam berbagai bentuk seperti berubahnya pengetahuan, pemahaman, sikap dan tingkah laku, keterampilan, kecakapan dan kemampuan, daya reaksi, daya penerimaan dan lain lain aspek yang ada pada individu yang belajar. Belajar adalah suatu kegiatan yang dilakukan peserta didik, bukan sesuatu yang dilakukan terhadap peserta didik. Pembelajaran yang berkualitas sangat tergantung dari motivasi peserta didik dan kreativitas pendidik. Peserta didik yang memiliki motivasi tinggi ditunjang dengan pendidik yang mampu memfasilitasi motivasi tersebut akan membawa pada keberhasilan pencapaian target belajar. Target belajar dapat diukur melalui perubahan sikap dan kemampuan siswa melalui proses belajar. Desain pembelajaran yang baik, ditunjang fasilitas yang memandai, ditambah dengan kreativitas pendidik akan membuat peserta didik lebih mudah mencapai target belajar.

Pada proses pembelajaran dibutuhkan kreativitas ataupun kemampuan dalam menggunakan metode untuk memecahkan persoalan yang ada di dalam pembelajaran. Disinilah pembelajaran kreatif perlu dikembangkan dalam proses pembelajaran. Perumusan kreativitas guru dalam penelitian ini lebih difokuskan kepada dua karakteristik guru kreatif yang diungkapkan oleh SC Utami Munandar (dalam Talajan, 2012:59) yakni "kreativitas guru dalam menemukan metode pembelajaran yang sesuai dengan tujuan pembelajaran dan untuk memecahkan masalah ( tujuan pembelajaran tidak tercapai dan siswa yang tidak antusias ) di dalam pembelajaran desain. Indikator motivasi belajar dapat diklasifikasikan sebagai berikut (Hamzah B. Uno, 2006:23), yaitu (1) Adanya hasrat dan keinginan berhasil; (2) Adanya dorongan dan kebutuhan dalam belajar; (3) Adanya harapan dan cita-cita masa depan; (4) Adanya penghargaan dalam belajar; (5) Adanya kegiatan yang menarik dalam belajar; (6) Adanya lingkungan belajar yang kondusif, sehingga 
memungkinkan seorang siswa dapat belajar dengan baik. Siswa termasuk bagian dari masyarakat. Berkembangnya potensi siswa dapat terwujud jika terciptanya masyarakat yang gemar belajar proses belajar yang efektif antara lain dilakukan melalui kegiatan membaca. Masyarakat yang gemar membaca memperoleh pengetahuan dan wawasan baru yang semakin meningkatkan kecerdasannya sehingga mereka lebih mampu menjawab tantangan hidup pada masa-masa yang akan datang. Kegemaran membaca merupakan salah satu kunci keberhasilan seseorang dalam meraih ilmu pengetahuan dan teknologi. Membaca merupakan sebuah keterampilan yang berkaitan erat dengan berbagai aspek pengetahuan, baik itu pengetahuan tentang ilmu sosial maupun sains. Ilmu sosial mencakup juga pembelajaran bahasa Indonesia. Bahkan membaca merupakan salah satu aspek ruang lingkup dalam pembelajaran bahasa Indonesia baik di sekolah dasar maupun sekolah menengah. Meskipun demikian, keterampilan membaca tidak terpaku hanya digunakan pada saat mempelajari aspek membaca, namun pada dasarnya aspek bahasa seperti mendengarkan, menulisdan berbicara juga tidak terlepas dari kegiatan membaca.

Burns, dkk (dalam Farida Rahim, 2007:1) menyatakan bahwa: Kemampuan membaca merupakan sesuatu yang vital dalam suatu masyarakat terpelajar. Namun, anak-anak yang tidak memahami pentingnya belajar membaca tidak akan termotivasi untuk belajar. Belajar membaca merupakan usaha yang terusmenerus, dan anak-anak yang melihat tingginya nilai (value) membaca dalam kegiatan pribadinya akan lebih giat belajar dibandingkan dengan anak-anak yang tidak menemukan keuntungan dari kegiatan membaca.

Sejalan dengan beberapa pendapat di atas, peneliti juga menemukan permasalahan yang sama ketika mengadakan wawancara dengan guru sd kelas V Sekolah SDN Karolina. Menurut hasil wawancara tersebut, masalah yang dihadapi oleh siswa yaitu masih kurangnya minat membaca dalam diri siswa, sehingga siswa kurang termotivasi untuk mempelajari materi-materi yang telah disampaikan oleh guru sebelumnya dan akhirnya berdampak pada hasil belajar siswa yang belum sesuai dengan apa yang diharapkan. 
Sardiman A. M (2010:75) menyatakan bahwa "Dalam kegiatan belajar, motivasi dapat dikatakan sebagai keseluruhan daya penggerak di dalam diri siswa yang menimbulkan kegiatan belajar, yang menjamin kelangsungan dari kegiatan belajar dan yang memberikan arah pada kegiatan belajar, sehingga tujuan yang dikehendaki oleh subjek belajar itu dapat tercapai.” Iskandar (2009:180) menyatakan bahwa "Motivasi belajar merupakan motivasi yang diterapkan dalam kegiatan belajar mengajar dengan keseluruhan penggerak psikis dari dalam diri siswa yang menimbulkan kegiatan belajar, menjamin kelangsungan belajar dalam mencapai suatu tujuan." Menurut Asep Jihad (2008:11), "Pembelajaran merupakan suatu prosesyang terdiri dari kombinasi dua aspek, yaitu: belajar tertuju pada apa yang harus dilakukan oleh siswa, mengajar berorientasi pada apa yang harus dilakukan oleh guru sebagai pemberi pelajaran. Yeti Mulyati (2007:4.1), yang menyatakan bahwa "Keterampilan membaca merupakan jenis keterampilan reseptif yang berkaitan erat dengan 3 jenis keterampilan berbahasa lainnya." Farida Rahim (2005:28) menyatakan bahwa "Minat membaca adalah keinginan yang kuat disertai usaha-usaha seseorang untuk membaca. Ada tiga fungsi motivasi menurut Oemar Hamalik (dalam Pupuh Fathurrohman dan M. Sobry Sutikno, 2007:20), yaitu (1) Mendorong manusia untuk berbuat, jadi sebagai penggerak atau motor yang melepaskan energi; (2) Menentukanarah perbuatan yakni ke arah tujuan yang hendak dicapai; (3) Menyeleksi perbuatan, yakni menentukan perbuatan-perbuatan yang harus dikerjakanyang serasi guna mencapai tujuan, dengan menyisihkan perbuatan-perbuatan yang tidak bermanfaat bagi tujuan tersebut.

pembelajaran Karakter berkaitan dengan pengetahuan moral (moral knowing), perasaan moral (moral feeling), dan perilaku moral (moral action). Karakter yang baik terdiri atas pengetahuan tentang kebaikan, keinginan untuk berbuat baik, dan berbuat kebaikan. Ketiga hal inilah yang menentukan kehidupan bermoral. Dalam komponen pengetahuan moral (moral knowing) terdapat enam aspek yaitu: (1) Kesadaran moral atau kesadaran hati nurani. Kesadaran moral dapat berkembang jika terdapat konsentrasi dan perhatian terhadap moral itu sendiri. Kesadaran moral secara bertahap dapat mengalami berkembang kualitasnya sesuai dengan makin terang dan 
jelasnya konsentrasi dan perhatian terhadap moral tersebut; (2) Pengetahuan nilainilai moral (knowing moral values) yang terdiri atas rasa hormat tentang kehidupan dan kebebasan, tanggung jawab, kejujuran, keterbukaan, tolenransi, kesopanan, disiplin diri, integritas, kebaikan, perasaan kasihan, dan keteguhan hati, dan keberanian untuk berbuat sesuai dengan kata hati; (3) Kemampuan untuk memberi pandangan (perspective-taking) kepada orang lain, melihat situasi secara objektif, membayangkan bagaimana seharusnya berpikir, bereaksi, dan merasakan. Memahami sudut pandang dari sisi orang lain dan membayangkan bagaimana orang lain berpikir dan merasakan. Jadi, sebelum bertindak perlu dipikirkan terlebih dahulu apakah tindakan yang kita lakukan akan dianggap baik dan disenangi orang lain atau tidak; (4) Pertimbangan dan penalaran moral (moral reasoning) adalah pemahaman tentang apa yang dimaksud bermoral dan mengapa kita harus bermoral; (5) Pengambilan keputusan (decision-making) adalah kemampuan untuk mengambil keputusan berdasarkan kata hati atau hati nurani dalam menghadapi masalah-masalah moral; dan (6) Kemampuan untuk mengenal dan memahami diri sendiri (self-knowledge).

Klasifikasi hasil belajar menurut Benyamin Bloom (Nana Sudjana,2010: 22-23) yaitu (1) ranah kognitif, berkenaan dengan hasil belajar intelektual (2) ranah afektif, berkenaan dengan sikap (3) ranah psikomotorik, berkenaan dengan hasil belajar yang berupa keterampilan dan kemampuan bertindak.

Surya, menyatakan bahwa belajar ialah bahwa suatu proses yang dilakukan individu untuk memperoleh suatu perubahan tingkah laku yang secara keseluruhan, sebagai hasil dari pengalaman individu itu sendiri dalam interaksi dengan lingkungannya.

Pengguna pedoman kegiatan pembelajaran: (1) guru sebagai individual atau kelompok guru (guru mata pelajaran, guru kelas, dan guru pembina kegiatan ekstrakurikuler) (2) pimpinan satuan pendidikan (kepala sekolah, wakil kepala sekolah, dan wakil kelas) (3) guru bimbingan dan konseling atau konselor sekolah (4) tenaga kependidikan. Motivasi mempunyai peranan penting dalam proses belajar mengajar baik bagi guru maupun siswa. bagi guru mengetahui motivasi belajar dari siswa sangat diperlukan guna memelihara dan meningkatkan semangat belajar siswa. 
bagi siswa motivasi belajar dapat menumbuhkan semangat belajar sehingga siswa terdorong untuk melakukan kegiatan belajar.

\section{METODE}

Metode yang digunakan dalam penelitian ini adalah metode deskriptif. Menurut Hadari Nawawi (2007:67), "Metode deskriptif dapat diartikan sebagai prosedur pemecahan masalah yang diselidiki dengan menggambarkan atau melukiskan keadaan subjek atau objek penelitian (seseorang, lembaga, masyarakat dan lain-lain) pada saat sekarang berdasarkan fakta-fakta yang tampak, atau sebagaimana adanya." Hal ini sesuai dengan masalah yang akan diteliti yaitu peneliti hendak menggambarkan keadaan nyata yang terjadi pada saat penelitian dilaksanakan, yakni menggambarkan objek penelitian tentang minat membaca dan motivasi belajar siswa kelas V SDN karolina. Dalam penelitian ini, peneliti menggunakan bentuk penelitian studi hubungan (Interrelationship Studies) dengan maksud untuk mencari ada tidaknya hubungan antara variabel bebas dengan variabel terikat. Bentuk penelitian ini dipilih karena sesuai dengan bentuk penelitian yakni untuk menentukan tingkat hubungan sebab akibat antara minat membaca dengan motivasi belajar siswa kelas V SDN karolina.

Menurut Sugiyono (2011:117), "Populasi adalah wilayah generalisasi yang terdiri atas: obyek/subyek penelitian yang mempunyai kualitas dan karakteristik tertentu yang ditetapkan oleh peneliti untuk dipelajari dan kemudian ditarik kesimpulannya." Adapun yang menjadi populasi dalam penelitian ini adalah seluruh siswa kelas $\mathrm{V}$ SDN karolina. Menurut M. Toha Anggoro, dkk (2008:4.3), "Sampel adalah sebagian anggota populasi yang memberikan keterangan atau data yang diperlukan dalam suatu penelitian. Dengan kata lain sampel merupakan himpunan bagian dari populasi." Teknik pengambilan sample dalam penelitian ini ialah menggunakan teknik Simple Random Sampling. Menurut Sugiyono (2011:120), "Simple Random Sampling dilakukan secara acak tanpa memperhatikan strata yang ada dalam populasi tersebut." Teknik ini dipilih oleh peneliti karena semua siswa kelas $\mathrm{V}$ tidak memiliki strata dan dianggap memiliki kemampuan yang sama/homogen. Teknik pengumpul data yang digunakan dalam penelitian ini ada tiga teknik, yaitu teknik observasi langsung, teknik 
komunikasi langsung dan teknik komunikasi tidak langsung. Menurut Hadari Nawawi (2001: 100), “Teknik observasi langsung dilakukan terhadap obyek di tempat terjadi atau berlangsungnya peristiwa, sehingga observer berada bersama obyek yang diselidikinya." Teknik komunikasi langsung menurut Hadari Nawawi (2007:101) adalah cara mengumpulkan data yang mengharuskan seorang peneliti mengadakan kontak langsung secara lisan atau tatap muka (face to face) dengan sumber data, baik dalam situasi yang sebenarnya maupun dalam situasi yang sengaja dibuat untuk keperluan tersebut. Hadari Nawawi (2007:101) menyatakan bahwa "Teknik komunikasi tidak langsung adalah cara mengumpulkan data yang dilakukan dengan mengadakan hubungan tidak langsung atau dengan perantara alat, baik berupa alat yang sudah tersedia maupun alat khusus yang dibuat untuk keperluan itu."

\section{HASIL DAN PEMBAHASAN}

Berdasarkan hasil survey tersebut, kurangnya minat membaca terjadi pada anak usia Sekolah Dasar. Ini merupakan tantangan bagi para guru Sekolah Dasar agar turut meningkatkan minat membaca peserta didiknya melalui berbagai upaya sehingga para peserta didiknya memiliki minat membaca yang tinggi. Pada kenyataannya kemampuan membaca dalam diri seorang siswa masih kurang baik, karena minat mereka pada kegiatan membaca juga masih sangat kurang di tingkat pendidikan dasar, kebiasaan membaca anak-anak masih rendah. Survey yang pernah dilakukan mencatat, kemampuan membaca anak SD di Indonesia menempati peringkat ke-26 dari 27 negara yang disurvei. Untuk dapat meningkatkan kemampuan berfikir kreatif sistematis siswa diperlukan sebuah teknik pembelajaran sebuah teknik pembelajaran yang dapat merangsang kemampuan berfikir.

Berdasarkan hasil penelitian kelas V SDN KAROLINA diketahui bahwa guru menggunakan metode pembelajaran ceramah, prakrek, Tanya jawab dan Adapun penugasan pengertian dari metode ceramah adalah metode yang sering disebut sebagai metode ekspositori yaitu kurangnya dominasi guru setelah memberikan penejelasan materi dan contoh soal. Hasil wawancara dengan guru kelas V SDN KAROLINA diketahui bahwa pembelajaran menggunakan metode ceramah, praktek, Tanya jawab dan penugasan. Namun siswa belum mampu untuk memahami materi 
yang diberikan. Berdasarkan hasil observasi diketahui bahwa dalam kegiatan pembelajaran desain menunjukan rendahnya minat belajar siswa untuk mengikuti pembelajaran, terlihat siswa memiliki kesibukan diluar konteks pembelajaran, seperti mengobrol diluar konteks pembelajaran, memiliki jawaban yang sama saat diberikan tugas, tidak bisa menjawab pertanyaan yang diberikan oleh guru dan tidur saat proses pembelajaran, minat membaca dan motivasi belajar siswa kelas V SDN KAROLINA tersebut, dengan demikian maka diterima yaitu terdapat pembelajaran yang signifikan antara minat membaca dan motivasi belajar siswa kelas V SDN KAROLINA. Minat membaca siswa "baik" maka motivasi siswa dalam belajar juga menunjukkan kategori "baik". Observasi ini bertujuan sebagai teknik pengumpulan data yang berguna untuk mencari informasi tentang minat membaca dan motivasi belajar siswa. Observasi ini bertujuan sebagai teknik pengumpulan data yang berguna untuk mencari informasi tentang minat membaca dan motivasi belajar siswa. Hasil kegiatan observasi ini kemudian diolah dan dijadikan sebagai data pendukung dari data hasil pengisian angket minat membaca dan motivasi belajar siswa. Menurut hasil wawancara tersebut, masalah yang dihadapi oleh siswa yaitu masih kurangnya minat membaca dalam diri siswa, sehingga siswa kurang termotivasi untuk mempelajari materi-materi yang telah disampaikan oleh guru sebelumnya dan akhirnya berdampak pada hasil belajar siswa yang belum sesuai dengan apa yang diharapkan. Berdasarkan permasalahan di atas, maka terlihat bahwa minat membaca memiliki hubungan dengan motivasi belajar siswa. Akan tetapi hubungan ini belum dapat teridentifikasi secara jelas. Hal inilah yang membuat peneliti tertarik untuk meneliti dan menganalisis lebih jauh mengenai "Pembelajaran antara Minat Membaca dengan Motivasi Belajar Siswa Kelas V SDN KAROLINA agar diketahui jawaban yang jelas atas permasalahan ini. Tujuan nya adalah Untuk mendeskripsikan minat membaca, supaya anak menjadi giat lagi dalam pembelajaran, membaca, semangat dalam belajar dan motivasi belajar harus didukung oleh kedua orang tua dan seseorang yang ada disekelilingnya supaya anak semangat dalam belajar dan menjadi anak yang sukses dimasa depan yang akan datang.

Apabila seseorang berperilaku tidak jujur, kejam, atau rakus, dapatlah dikatakan orang tersebut memanisfestasikan perilaku buruk. Sebaliknya, apabila seseorang berperilaku jujur, bertanggung jawab, suka menolong, tentulah orang tersebut 
memanifestasikan karakter baik. Istiah karakter erat kaitannya dengan 'personality'. Seseorang baru bisa disebut 'orang yang berkarakter' (a person of character) apabila tingkah lakunya sesuai dengan kaidah moral. Dengan demikian, pendidikan karakter yang baik harus melibatkan bukan saja aspek pengetahuan yang baik (moral knowing), tetapi juga merasakan dengan baik atau loving the good (moral feeling) dan perilaku yang baik (moral action). Hal ini sejalan pula dengan Lickona(1992:53)yangmengemukakan bahwa komponen karakter yang baik harus meliputi moral knowing, moral feeling, dan moral action.

Kebhinekaan merupakan karakteristik masyarakat kita dan telah mengakar dalam kehidupan indonesia. hal ini mengindikasikan bahwa kebhinekaan ini bukan muncul secara tiba-tiba, melainkan melalui proses panjang dalam perjalanan sejarah masyarakat indonesia. motto bhineka tunggal ika dalam genggaman garuda pancasila menunjukkan bahwa bangsa indonesia senantiasa berkomitmen untuk hidup rukun dalam keberagaman agama, budaya, suku, aliran dan asal keturunan serta berbagai perbedaan yang lainnya. sikap toleransi dan keteladanan menyikapi perbedaan yang dicontohkan para founding father indonesia harus ikuti seluruh komponen bangsa dan merawat agar mampu bersinergi dan berkolaborasi sesama anak bangsa, namun disisi lain perlu juga diwaspadai agar tidak melahirkan etnosentrisme dan singkretisme yang menimbulkan keracunan dan kekacauan serta konflik sosial.

motivasi menurut purwanto (2017: 60) menyatakan bahwa motivasi adalah segala sesuatu yang mendorong seseorang untuk bertindak melakukan sesuatu. menurut Djamarah (2015: 149-151) dikenal dua macam motivasi yaitu (1) motivasi intrinsik, djamarah (2015: 149) berpendapat behwa motivasi instrinsik motif atau menjadi aktif atau berfungsinya tidak perlu dirangsang dari luar, karena dalam diri individu sudah ada dorongan untuk melakukan sesuatu (2) motivasi ekstrinsik, tujuan utama individu melakukan kegiatan adalah untuk mencapai tujuan yang terletak diluar aktivitas belajar itu sendiri, atau tujuan itu tidak terlibat dalam aktivitas belajar.

Metode-metode dalam psikologi pembelajaran: (1) metode eksperimen adalah untuk mengetes keyakinan atau pendapat tentang tingkah laku manusia dalam situasi atau kondisi tertentu (2) metode observasi, adalah untuk mempelajari gejala kejiwaan melalui pengamatan dengan sengaja, teliti, sistematis. (3) metode genetik, metode ini 
juga disebut metode perkembangan, merupakan teknik observasi yang digunakan masa pertumbuhan mental dan fisik anak dan juga hubungannya dengan anak-anak lain dan orang-orang dewasa, yakni perkembangan sosial, kemudian dicatat dengan cermat. (4) metode riwayat hidup atau klinis, metode ini untuk menyelidiki gejalagejala kejiwaan dengan jalan mengumpulkan riwayat hidup sebanyak-banyaknya, baik yang ditulis sendiri maupun yang ditulis oleh orang lain. (5) metode tes, tes adalah suatu alat yang didalamnya berisi sejumlah pertanyaan yang harus dijawab atau perintah-perintah yang dikerjakan, untuk mendapatkan gambaran-gambaran tentang kejiwaan seseorang atau kelompok.

sebagai suatu proses pengaturan, kegiatan belajar mengajar tidak terlepas dari ciri-ciri tertentu, menurut Edi Suardi kegiatan belajar mengajar sebagai berikut: (a) belajar mengajar memiliki tujuan, yakni untuk membentuk anak didik dalam suatu perkembangan tertentu. (b) ada suatu prodesur (jalannya interaksi) yang direncanakan didesain untuk mencapai tujuan yang telah ditetapkan. (c) kegiatan belajar mengajar ditandai dengan satu penggarapan materi yang khusus. (d) ditandai dengan aktivitas anak didik (e) dalam kegiatan belajar mengajar, guru berperan sebagai pembimbing. (f) dalam krgiatan belajar membutuhkan disiplin. (g) ada batas waktu. (h) evaluasi. pembelajaran tidak terlepas dari pengertian belajar, belajar dan pembelajaran menjadi satu rangkaian kegiatan yang tidak dapat dipisahkan. pendidikan berorientasi kecakapan hidup, pembelajaran berbasis kompetensi, dan proses pembelajaran yang diharapkan menghasilkan produk yang bernilai. lingkungan belajar yang dimaksud situasi belajar, sumber-sumber data primer digunakan agar menjamin keautentikan dan kompleksitas dunia nyata, mengembangkan kecakapan hidup, mengembangkan kecakapan ini berada didalam konteks individual, kompetensi sebelumnya keyakinan, keterampilan memecahkan masalah, peserta didik diberi peluang untuk belajar kompleksitas pengetahuan, belajar kooperatif dan kolaboratif, penilaian autentik menjadikan penilaian yang tak terpisahkan dari kegiatan pembelajaran.

keberhasilan proses pembelajaran sangat ditentukan oleh keterampilan guru dalam mendesain pendidikan. guru yang memiliki sejumlah kompetensi dan keterampilan yang baik dapat mudah mendesain pembelajaran dan mengajarkannya 
dikelas, sehingga dapat mengantarkan peserta didik dalam mencapai hasil belajar yang optimal. secara sederhana pembelajaran diperuntukan dalam membantu proses belajar peserta didik sehingga menjadi sebuah sistem yang mencakup seluruh proses pembelajaran mulai dari analisis, desain, pengembangan implementasi dan proses hasil pembelajaran. pembelajaran berbasis lembar kerja alternative solutions worksheet (ASW) diharapkan salah satu inernatif untuk meningkatkan kemampuan berfikir kratif matematis siswa. berfikir merupakan sebuah tindakan yang tidak gegabah dan menggunakan akal rasional dengan menentukan keputusan. Evans (2012) mengatikan krartivitas sebagai kemampuana auntuk mencipta atau berkreasi.

berdasar pada sifat-sifat pengetahuan dan proses penemuan ilmiah dalam sains, memungkinkan bagi orang yang senantiasa membiasakan diri berfikir dan bekerja secara ilmiah akan tumbuh dan berkembang perilaku karakter pada dirinya. sikap ilmiah yang dimaksud sesuai dengan sejumlah perilaku karakter yang terdapat berbagai kepustakaan yang membahas mengenai pendidikan karakter diindonesia. lebih khusus adalah perilaku karakter pancasila menuju generasi 2045. dalam kedudukannya sebagai mata pembelajaran, sains (semua disiplin ilmu yang mencakup didalamnya) wajib dipelajari oleh sebagian besar peserta didik pada setiap jenjang dan satuan pendidikan yang ada diindonesia. dengan demikian pendidikan sains berperan dalam upaya mewujudkan fungsi dan tujuan pendidikan nasional indonesia, yang tercantum pasa pasal 3 undang-undang republik indonesia nomor 20 tahun 2003 tentang sistem pendidikan nasional.

\section{KESIMPULAN}

Pembelajaran adalah aktivitas yang paling utama. Hal ini berarti bahwa keberhasilan suatu individu dalam pencapaian tujuan pendidikan banyak bergantung pada bagaimana pembelajaran dapat berlangsung secara efektif. Pembelajaran yaitu suatu proses yang dilakukan dengan memberikan pendidikan dan pelatihan kepada peserta didik untuk mencapai hasil belajar. Hasil wawancara dengan guru kelas $\mathrm{V}$ SDN KAROLINA diketahui bahwa pembelajaran menggunakan metode ceramah, praktek, Tanya jawab dan penugasan. Namun siswa belum mampu untuk memahami materi yang diberikan. Berdasarkan hasil observasi diketahui bahwa dalam kegiatan 
pembelajaran desain menunjukan rendahnya minat belajar siswa untuk mengikuti pembelajaran, terlihat siswa memiliki kesibukan diluar konteks pembelajaran, seperti mengobrol diluar konteks pembelajaran, memiliki jawaban yang sama saat diberikan tugas, tidak bisa menjawab pertanyaan yang diberikan oleh guru dan tidur saat proses pembelajaran, minat membaca dan motivasi belajar siswa kelas V SDN karolina tersebut, dengan demikian maka diterima yaitu terdapat pembelajaran yang signifikan antara minat membaca dan motivasi belajar siswa kelas V SDN karolina. dalam pembelajaran, minat membaca dan motivasi belajar ini supaya anak minat membaca dalam pembelajaran, supaya anak menjadi giat lagi dalam pembelajaran, membaca, semangat dalam belajar dan motivasi belajar harus didukung oleh kedua orang tua dan seseorang yang ada disekelilingnya supaya anak semangat dalam belajar dan menjadi anak yang sukses diamsa depan yang akan datang.

\section{SARAN}

Ada beberapa saran yang dapat peneliti sampaikan berdasarkan hasil penelitian yaitu (1) Hendaknya orangtua, guru maupun masyarakat harus mampu membantu siswa untuk terus meningkatkan minat membacanya melalui berbagai cara untuk menunjang yang ada pada diri siswa agar para generasi muda terutama siswa sekolah dasar memiliki kebiasaan atau minat membaca yang tinggi. Karena hal ini merupakan awal dari kesuksesan mereka di masa yang akan datang. (2) Hendaknya guru lebih kreatif dan inovatif dalam mengemas pembelajaran di kelas, sehingga siswa selalu merasa termotivasi dalam belajar di kelas. (3) Hendaknya orangtua, masyarakat maupun guru harus mampu mendorong para generasi muda untuk membudayakan kegiatan membaca dalam kehidupannya, karena jika kegiatan membaca sudah membudaya dalam kehidupan para generasi muda khususnya siswa sekolah dasar, maka motivasi belajar siswa melalui kegiatan membaca pun akan meningkat, sehingga akan berdampak pada hasil belajar siswa yang sesuai dengan harapan. 


\section{DAFTAR PUSTAKA}

Heri effendi, s. a. (2020). Buku model pembelajaran sejarah islam berbasis kebbinnekaan (PSI-BK). Jl. raya wangandowo, bojong pekalongan, jawa tengah 51156: PT Nasya Expanding Management.

lestari, E. t. (2020). Cara praktis meningkatkan motivasi siswa sekolah dasar. Jl. rajawali, G. elang 6, No 3, drono, sardonoharjo, ngaglik, sleman: PENERBIT DEEPUBLISH.

M. Ismail makki, A. (2019). Konsep dasar belajar dan pembelajaran. Jl. masjid nurul falah lekoh barat bangkes kadur pamekasan: Duta media publishing.

pamawi, A. (2019). PSIKOLOGI BELAJAR. Jl. rajawali, G. elang 6 No.3 drono, sardonoharjo, ngaglik, sleman: PENERBIT DEEPUBLISH.

Rusman. (2017). Belajar dan pembelajaran berorientasi standar proses pendidikan. Jl. tambra raya No.23 rawamangun-jakarta 13220: KENCANA.

Abidin, Y. (2012). MODEL PENILAIAN OTENTIK DALAM PEMBELAJARAN MEMACA PEMAHAMAN. Jurnal Pendidikan Karakter, Tabun II, Nomor 2, .

Buchori Achmad, M. M. (2016). Keefektifan Model Pembelajaran LC5E dan Crh Berbantuan Multimedia Interaktif Terhadap Hasil Belajar Siswa.

Puewanti, D. (2017). Pendidikan Karakter Peduli Lingkungan dan Implementasi. DWIJACENDEKIA, Jurnal Riset Pedagogik, 1(2), 14-20.

Usman Arifin, R. P. (2017). Penerapan Pembelajaran Berbasis Alternatif Solutions Workheet Untuk Meningkatkan Kemampuan Berfikir Kreatif Matematik . Jurnal Pendidikan Matematika FKIP Univ. Muhammadiyah Metro, 226.

Wayan Sadia, B. A. (2013). Model Pendidikan Karakter Terintegrasi Pembelajaran Sains. Universitas Pendidikan Ganesha. 